\title{
Somatic, Auditory, Visual and Intellectual (SAVI) Learning Models Affect Students 'Mathematics Learning Achievement
}

\section{Leni Fajriah', Meiliana Nurfitriani2, Rahmat Permana ${ }^{3}$}

123 PGSD, FKIP, Universitas Muhammadiyah Tasikmalaya, Indonesia

\author{
ARTICLEINFO \\ Article history: \\ Received 2 Juni 2020 \\ Received in revised form \\ 12 Juli 2020 \\ Accepted 10 Agustus 2020 \\ Available online 28 Agustus \\ 2020 \\ kata kunci: \\ Model Pembelajaran, SAVI, \\ Prestasi Belajar \\ keywords: \\ SAVI, Learning \\ achievement
}

\begin{abstract}
A B S T R A K
Rendahnya prestasi belajar matematika siswa yang disebabkan kurang optimalnya penggunaan model pembelajaran yang inovatif menyebabkan siswa sulit memahami materi pembelajaran penyebab penelitian ini dilakukan. Tujuan penelitian ini adalah untuk menganalisis pengaruh penerapan pembelajaran Somatic, Auditory, Visual dan Intellectual (SAVI). Jenis penelitian yang digunakan adalah penelitian eksperimen, dengan data kuantitatif. Penelitian ini menggunakan rancangan eksperimen The Non-Equivalent Group Design. Populasi penelitian ini adalah seluruh siswa kelas V yang berjumlah 61 siswa. Teknik dalam menentukan sampel penelitian adalah random sampling. Metode tes dan wawancara digunakan dalam mengumpulkan data penelitian. Diperoleh hasil analisis data yang menunjukan rerata prestasi belajar matematika siswa pada kelompok yang diberikan model pembelajaran SAVI mendapatkan hasil 83,6 sedangkan rerata prestasi belajar matematika siswa pada kelompok yang dibelajarkan secara konvensional mendapatkan hasil 61,66.
\end{abstract}

Perbedaannya juga dapat dilihat dari rata-rata $\mathrm{N}$ gain yaitu kelas eksperimen 0.68 dengan kategori cukup efektif, sedangkan untuk rata-rata $\mathrm{N}$ gain kelas kontrol 0.22 dengan kategori tidak efektif. Dengan demikian terdapat perbedaan signifikan prestasi belajar matematika siswa antara kelas eksperimen yang menggunakan model pembelajaran SAVI dengan kelas kontrol yang tidak menggunakan model pembelajaran SAVI.

\section{A B S T R A C T}

The low mathematics learning achievement of students due to the less than optimal use of innovative learning models makes it difficult for students to understand the learning material as the reason why this study was conducted. The purpose of this study was to analyze the effect of the application of Somatic, Auditory, Visual and Intellectual (SAVI) learning. This type of this study was expresearcherimental research, with quantitative data. This study used the experimental design of The Non-Equivalent Group Design. The population of this study were all students of class $\mathrm{V}$, amounting to 61 students. The technique in determining the research sample is random sampling. Test and interview methods were used in collecting research data. The results of data analysis showed that the average mathematics learning achievement of students in the group given the SAVI learning model got 83.6 results while the average mathematics learning achievement of students in the conventional taught group got 61.66 results. The difference can also be seen from the average $\mathrm{N}$ gain, namely the experimental class is 0.68 in the quite effective category, while for the average $\mathrm{N}$ gain, and the control class is 0.22 , in the ineffective category. Thus, there is a significant difference in students' mathematics learning achievement between the experimental class that uses the SAVI learning model and the control class that does not use the SAVI learning model.

\section{Introduction}

In the learning process the teacher is the most important factor in achieving maximum learning goals. Teachers have a duty to develop students' knowledge and skills. A meaningful learning process will improve students' ability to develop knowledge (Jailani, 2017). Developing innovative and meaningful learning for students is not easy. Factors that influence it are students' interest and motivation in learning, teacher readiness to design learning that can stimulate students (Donas Ahmad Najib \& Elhefni, 2016). Designing meaningful learning is a difficult challenge for teachers; teachers are required to be more creative and innovative in designing interesting learning so that students are motivated to learn. The learning design that is not suitable will have a negative impact on student achievement. Student learning achievement shows that he has experienced a learning

Copyright (C) Universitas Pendidikan Ganesha. All rights reserved.

${ }^{1}$ Corresponding author.

E-mail addresses: leni fajriah11@gmail.com¹ (Fajriah), meiliana88@gmail.com² (Nurfitriani), permana.rahmat98@gmail.com ${ }^{3}$ (Permana). 
process and has experienced changes in knowledge. Learning achievement can show a person's level of success after carrying out the learning process. This is because learning achievement is the result of assessments learned during the learning period. Learning achievement can also be called an actual ability (actual ability) obtained by someone after learning, a potential skill, namely the basic ability in the form of a disposition that is owned by an individual to achieve achievement (Rahmah, Nur, \& Asnida, 2015; Wiryawan, Murda, \& Bayu, 2019).

Currently there are still many students who experience problems in achieving optimal learning achievement. This is because many students are only passive in class and only accept teacher delivery. Learning cannot run optimally if many students are not active in class and tend to only listen to the teacher (Anika \& Fajar, 2020; Umbara, dkk, 2020). This is because the teacher does not design learning attractively so that it seems monotonous. Learning that occurs in the classroom should be able to increase student motivation in learning so that it has a positive impact on student achievement. More specific problems faced in learning mathematics. The math ability of each child is different; most students still think that mathematics is a lesson that is difficult to compare with other subjects, especially for students at the basic education level. Ruseffendi (2006) said that many students after learning mathematics, even the simplest parts are not understood, many concepts are misunderstood. Mathematics is considered a difficult science; this can be seen from the various obstacles that not all students can understand learning materials so that a mathematics learning model must be established that can foster student interest in learning. Therefore, teachers must be able to motivate students so that student interest in learning grows conducive to students. This is supported by the results of observations made in one elementary school.

Based on the results of interviews with homeroom teachers, grade V at SDN 1 Awipari, learning achievement on the results of daily tests of mathematics subject matter building space $57.14 \%$ of class V SDN 1 Awipari students have not passed the minimum completeness criteria standard (KKM) in mathematics learning set by the school, namely 75 . In addition, the conventional learning model is dominantly used by the teacher in the learning process so that students feel bored, sleepy, and lack of interaction in the learning process. Some students have not fully mastered the material provided by the teacher and this is evidenced by many students who get grades under the KKM. If problems like this are left unchecked, it will continue to impact low student achievement.

In improving student learning achievement, several efforts are made that can be applied by the teacher. One of them is the application of an innovative learning model that can make students interested and motivated in learning. (Ngalimun, 2017; Puspita, Asri, \& Ardana, 2019) also stated that in observing the learning situation the teacher should determine innovative learning strategies so that learning objectives can be achieved and students play an active role when learning activities take place. The role of the teacher is very important, so the teacher should actively develop interactive and meaningful concepts and learning models for students. The learning process in the classroom has not fully utilized all student learning modalities, such as visual, audio, and intellectual. The learning process still uses the old learning paradigm in the sense that communication in mathematics learning tends to take place in one direction, generally from teacher to student, the teacher dominates the learning, so learning tends to be monotonous, resulting in students feeling bored. Thus, in the process of learning mathematics must choose the right model. The learning model will be good depending on the learning objectives, suitability with learning material, the level of development of students (students), the ability of teachers to manage learning and optimize existing learning resources (Alwan, 2020; Daryanto, 2011). Therefore, in teaching mathematics to students, they should choose a learning model that is appropriate to the situation so that the planned learning learning objectives will be achieved. One of the learning models suitable to be applied to mathematics lessons is the Somatic, Auditory, Visual and Intellectual (SAVI) learning model.

The SAVI learning model is a learning model that utilizes all of the student's sensory tools which are used as learning media. This SAVI learning model has four elements, namely Somatic, Auditory, Visual and Intellectual (Andrianti, Irawati, \& Sudin, 2016; Muniroh, Maftukhin, \& Sriyono, 2015). Meier inside (Khoirudin, 2017) stated that the SAVI model presents a complete system for involving senses and emotions in the learning process which is a natural way of learning known as the SAVI model. The SAVI learning model allows students to be actively involved by combining physical movement and intellectual activity and directs students to seek various alternative information from various sources that they get through the five senses. The use of the SAVI learning model in mathematics learning is considered important because the SAVI learning model can optimize all five senses in learning directly in one event, not only hearing and seeing teacher explanations, but there is visual media to see, students try to explain and practice lessons, peer discussion, and ask fellow friends and teachers so that student learning becomes more active. The 
SAVI learning model will create learning activities that not only benefit one group of student learning styles, but all students with various learning styles are able to receive learning material. The results of research conducted by Muniroh et al (2015) stated that the SAVI learning model is said to be effective in improving student learning outcomes with the percentage of student learning outcomes obtained by $86.2 \%$. and student activeness increased to $89.31 \%$. Research conducted by Irfan \& Nasriadi (2019) stated that the SAVI learning model was effectively applied in learning fractions, students became active and enthusiastic in participating in learning. Wati, Darsana, \& Suardika (2014) also stated that the application of the SAVI learning model can improve student learning outcomes.

Based on this explanation, the formulation of the purpose of this study is to analyze the effect of the application of Somatic, Auditory, Visual and Intellectual (SAVI) learning. The steps for implementing this model are adjusted to the syntax of the SAVI learning model, namely (1) the preparation stage, (2) the delivery stage, (3) the training stage, and the performance stage. By implementing Somatic, Auditory, Visual and Intellectual (SAVI) learning model, it is hoped that it can improve students' mathematics learning achievement. The learning model ii can be an alternative for teachers in implementing innovative learning so that learning objectives can be achieved.

\section{Research Method}

The experimental design form developed in this study was Quasi Experimental Design. Quasi Experimental Design was used because in reality it is difficult to get a control group to use for research (Sugiyono, 2016). This study used the experimental design of The Non-Equivalent Group Design. This design used 2 groups, namely the experimental class and the control class. The experimental class is a group that is given treatment with the application of the SAVI learning model (Somatic, Auditory, Visual, Intellectual), while the control class group is the control group, namely the untreated class.

The population in this study was all fifth-grade students of SD Negeri 1 Awipari, totaling 61 students. This study uses 2 classes that are used as samples. The first class was called the experimental class with special treatment in the form of the SAVI learning model and the second class was the control class that applies the conventional / lecture model. The sample used in this study was 29 people as the experimental class and 32 people as the control class.

The method used in this research was an experimental method, with quantitative data. The object of this research was the influence of the SAVI (X) learning model on student achievement (Y). The steps in carrying out this research are as follows. 1) Selecting two groups of subjects to be used as the experimental group and the control group. 2) Develop research instruments. 3) Testing research instruments. 4) Give a pretest to both groups. 5) Provide treatment to the experimental class by applying the SAVI learning model. 6) After doing the fifth step then giving posttest to both groups. 7) Finding the mean of the two groups between the pretest and posttest. 8) Using statistics to find the effect of the results of the seventh step, so that it can be seen the effect of the Somatic, Auditory, Visual and Intellectual (SAVI) learning model on student achievement.

The data collection techniques used in this study were interviews and tests. Interviews were conducted with class teachers to obtain data or information about conditions in SDN 1 Awipari such as: student characteristics, school situations and to obtain student achievement data. In collecting test data, the writer used pre-test (pre-test) and post-test (final test). The purpose of this test is to determine the extent to which learners understand in learning a given material. The test consists of 15 multiple choice questions with four answer choices. Each correct answer gets a score of 1 while the wrong answer scores 0 . The test was carried out individually in both classes of the study sample with the same questions.

The analysis technique used in this research was quantitative analysis. This quantitative analysis used statistics using existing formulas and rules to simplify the calculation process in research. There were two kinds of statistics used, namely descriptive statistics and inferential statistics. Descriptive statistics are intended to find out the general description of each variable. Inferential statistics were used to prove the hypothesis proposed in this study. For statistical hypothesis testing in research, the type of average difference test statistic used could be determined by first performing a data assumption test consisting of a data distribution normality test, a variance homogeneity test and a hypothesis test. 


\section{Result and Discussion}

In this study, the validity of the question instruments was tested to determine the validity of the questions. Based on the results of the table above, $r$ table $(5 \%)$ for the number of respondents 45 people is 0.294 . $r$ count obtained after carrying out the validity test using SPSS 16 , the result of $r$ count from 15 questions is number 1 is 0.577 , number 2 is 0.321 , number 3 is 502, number 4 is 0.437 , number 5 is 0.326 , number 6 is 0.452 , number 7 is 0.575 , number 8 is 0.485 , number 9 is 0.324 , number 10 is 0.447 , number 11 is 0.326 , number 12 is 0.595 , number 13 is 0.591 , number 14 is 0.502 , and number 15 is 0.577. All $r$ counts from all 15 questions, the result is more than $r$ table (0.294) so that all questions are declared valid and the question instrument can be used for research and can be continued to test the reliability of the questions.

The reliability test in this study used the test with the help of SPSS 16 with the Cronbach's alpha formula with the following decision-making rules:

$$
\begin{aligned}
& \text { Cronbach's Alpha }>0,05=\text { reliable } \\
& \text { Cronbach's Alpha }<0,05=\text { not reliable }
\end{aligned}
$$

Based on the results of the SPSS 16 output, the reliability test can be seen in the following table:

Table 2. Reliability Test Results

\begin{tabular}{ll}
\hline Cronbach's Alpha & N of Item \\
\hline 746 & 15 \\
\hline
\end{tabular}

Based on the table above, it can be seen that Cronbach's alpha which has been tested has a value of 0.746 . So it can be concluded that $0.746>0.05$ so that all 15 questions are all reliable and can be used for research.

The data normality test is conducted to determine whether the data is normally distributed or not. In this study, the normality test used was using SPSS 16 with the Kolmogrov-Smirnov method with the provision of decision making if the significance level was $>0.05$, it could be said that the data were normally distributed. The results of the normality test using SPSS 16 can be seen in the following table:

Table 5. Normality Test Results

\begin{tabular}{lllll}
\hline \multirow{2}{*}{ Class } & \multicolumn{3}{l}{ Kolmogrov-Smirnov } \\
\cline { 2 - 5 } & & Statistic & Df & Sig \\
\hline \multirow{3}{*}{ Learning } & Pre-test Eksperimen & .971 & 29 & .599 \\
Outcomes & Post-test Eksperimen & .911 & 29 & .308 \\
& Pre-test Kontrol & .948 & 32 & .127 \\
& Post-test Kontrol & .962 & 32 & .302 \\
\hline
\end{tabular}

Based on the table above, it can be found that the data has a significance value $>0.05$. The significance value obtained from the pre-test and post-test values of the experimental class and control class is the experimental pre-test $0.599>0.05$, the experimental post-test $0.308>0.05$, the control pre-test $0.127>0.05$, and post-test control $0.302>0.05$. Thus it can be concluded that the data in this study, both the experimental class and the control class, were normally distributed.

The homogeneity test was a test conducted to determine whether the data is homogeneous or not. The homogeneity test in this study was to use the f count test by comparing the variance of data from the two groups and the rules of decision making if $\mathrm{f}$ count $<\mathrm{f}$ table then the data is homogeneous. The results of the homogeneity test in this study can be seen in the table as follows.

Table 6.Data Homogeneity Test Results

\begin{tabular}{llll}
\hline Pre-test & & Post-test & \\
\hline Varians pre-test eksperimen & 466.2235 & Varians post-test eksperimen & 90.85933 \\
Varians pre-test kontrol & 265.696 & Varians post-test kontrol & 255.1971 \\
F count & 1.754725 & F count & 0.356036 \\
db numerator $=\mathrm{n}-1$ & 28 & db numerator $=\mathrm{n}-1$ & 28
\end{tabular}




\begin{tabular}{llll} 
db denominator $=\mathrm{n}-1$ & 31 & db denominator $=\mathrm{n}-1$ & 31 \\
Significance level & 0.05 & Significance level & 0.05 \\
F table & 2,38 & F table & 2,38 \\
\hline
\end{tabular}

Based on the table above, it can be seen that $\mathrm{f}$ count of pretest data $<$ from $\mathrm{f}$ table is $1.754<2.38$ and $\mathrm{f}$ count of posttest data $<$ f table is $0.356<$ of 2.38 . That is, in accordance with the rules of decision making if $\mathrm{f}$ count $<\mathrm{f}$ table, the data is homogeneous.

After carrying out the normality and homogeneity test, the next step is to test the research hypothesis. Hypothesis testing in this study is the Independent Sample Test (t-test). The t-test was used to determine the difference in the average score of student achievement.

Based on the hypothesis that has been described in this study, namely:

$\mathrm{HO}=$ Somatic, Auditory, Visual, Intellectual (SAVI) Learning Model does not affect the mathematics learning achievement of fifth grade students at SDN 1 Awipari.

$\mathrm{Ha}=$ Somatic, Auditory, Visual, Intellectual (SAVI) Learning Model affects the mathematics learning achievement of fifth grade students at SDN 1 Awipari.

The results of t-test calculations using SPSS 16 can be seen in the table below.

Tabel 7. Test results of Independent Sample Test (T Test)

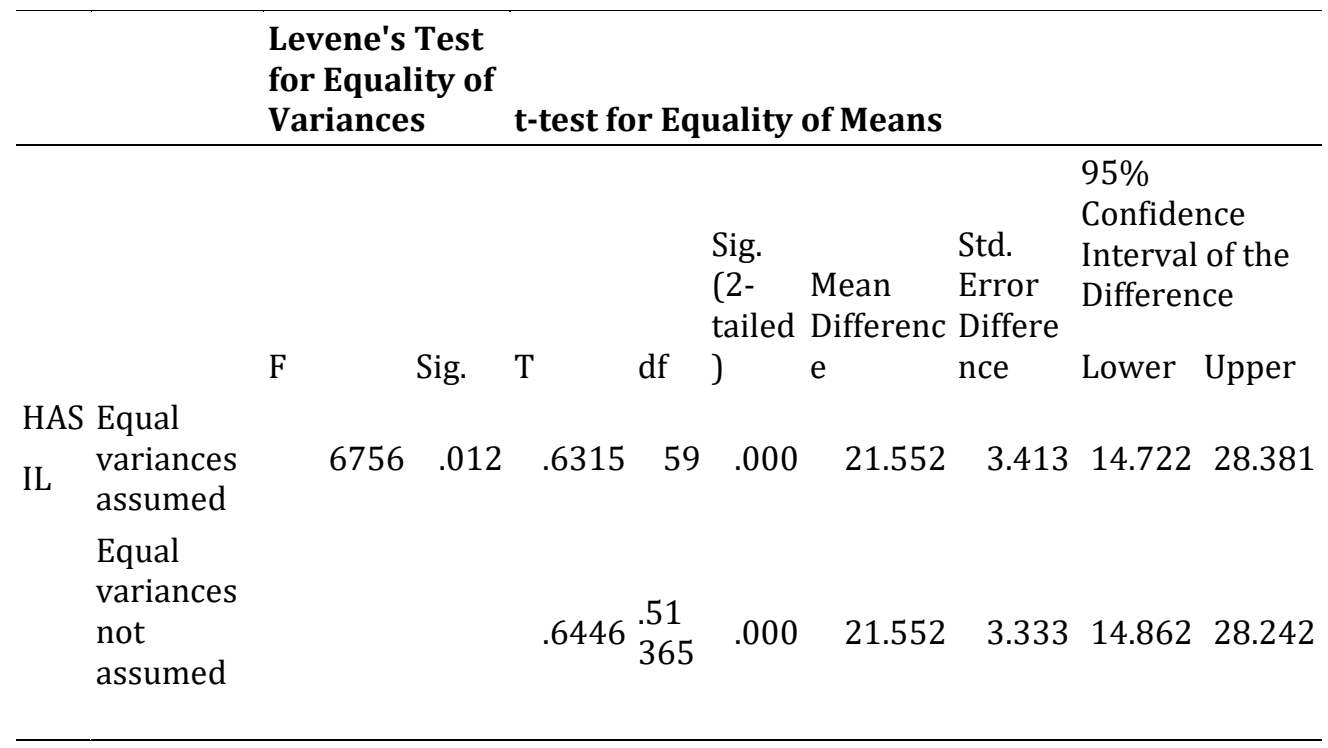

Based on the table above, the calculation on the difference test in the average value of student achievement in class $\mathrm{V}$ material on building space can be assessed by the decision rule if the value is significance or sig. (2-tailed) $>0.05$ then $\mathrm{HO}$ is accepted and Ha is rejected, whereas if the value is significance or sig. ( 2 -tailed) $<0.05$ then $\mathrm{HO}$ is rejected and Ha is accepted.

From the table of the results of the Independent Sample Test, the significance value is 0, 000 $<0.05$. So in accordance with the rules of decision making, because $0.000<0.05$, it can be concluded that $\mathrm{HO}$ is rejected and $\mathrm{Ha}$ is accepted. This means that the Somatic, Auditory, Visual, Intellectual (SAVI) Learning Model affects the mathematics learning achievement of fifth grade students at SDN 1 Awipari. Thus there is a significant effect of Somatic, Auditory, Visual, Intellectual (SAVI) learning models on elementary students' mathematics learning achievement. Somatic, Auditory, Visual, Intellectual (SAVI) learning models have a positive impact on students' mathematics learning achievement influenced by several factors, namely as follows.

First, the Somatic, Auditory, Visual, Intellectual (SAVI) learning model has an impact on the competence of mathematical knowledge because it can increase student activity. If students can understand ideas and concepts in mathematics, it will not be difficult to understand the next concept (Cahyati, Andriani, \& Revita, 2020; Moma, 2017). The SAVI learning model is learning that emphasizes that learning must take advantage of all the sensory organs that students have. Students can move (somatic), listen (auditory), observe (visual), and think (intellectualy), so that student activity will be seen, students will be physically and psychologically active. This is indicated by the average value of group learning outcomes using the Somatic, Auditory, Visual, Intellectual (SAVI) 
learning model is superior when compared to the average value of the conventional group learning outcomes. Learning activities in the experimental group using the Somatic, Auditory, Visual, Intellectual (SAVI) model of students are more active because students are more independent in solving problems. This is also supported by research conducted by Murti, Nasir, \& Negara (2019) stated that the SAVI learning model can improve student learning outcomes. Research conducted by Sutarna (2018) stated that the SAVI learning model can improve the ability to ask questions and express student opinions, increase students' critical thinking skills so that it has an impact on increased learning outcomes.

Second, the Somatic, Auditory, Visual, Intellectual (SAVI) learning model has an impact on student cognitive because it can improve students' creative thinking. The SAVI learning model is a learning model that is a complete system that involves emotions and the five senses in the learning process. The theory supporting the SAVI learning model is the right / left brain theory, triune brain, choice of modalities, multiple intelligence theory, and accelerated learning (F. A. Huda \& Yulianti, 2020; M. Huda, 2014). The SAVI learning model provides opportunities for students to think creatively and solve problems. This is supported by research conducted by (Khoirudin, 2017; Wati et al., 2014) which stated that the SAVI learning model has an impact on student cognitive so that it affects student learning outcomes that increase.

Third, the Somatic, Auditory, Visual, Intellectual (SAVI) learning model can increase students' independence in learning. The application of the SAVI learning model can optimize three modalities in students, which have an impact on students' independence in learning. In SAVI learning, there are 4 components as a characteristic of this model, namely Somatic Auditory Visual and Intellectual. Somatic is a body movement, which means that learning must be by experiencing or doing. Auditory is hearing, which means that the ear senses are used in the learning process by listening, listening, speaking, presenting, arguing, expressing opinions, and responding. Visual is vision, which means that learning must use the eyes through observing, drawing, painting, demonstrating learning media and teaching aids. Intellectual is thinking, which means that the ability to think must be trained through reasoning, creating, solving problems, constructing, and implementing (Sutarna, 2018; Wati et al., 2014). Penelitian yang dilakukan oleh Murti et al., (2019) stated that there is the influence of students with treatment using the SAVI learning model on improving mathematical problem solving abilities in algebraic factorization material better than students with learning treatment using conventional learning both in general and in terms of each category of students' mathematical learning independence.

\section{Conclusion}

Somatic, Auditory, Visual, Intellectual (SAVI) learning models have an effect on mathematics learning achievement. It can be seen from the results of the hypothesis test obtained, namely H0 is rejected and Ha is accepted. It can be concluded that the Somatic, Auditory, Visual, Intellectual (SAVI) learning model affects the mathematics learning achievement of grade V students at SDN 1 Awipari.

\section{References}

Alwan, M. (2020). Pengaruh Strategi Pembelajaran Cooperative Learning Tipe Rotating Trio Exchange Terhadap Prestasi Belajar Matematika Siswa Mts. Jurnal Al-Muta'aliyah STAI Darul Kamal NW Kembang Kerang, 5(1), $2502 \quad$ - 2474. http://ejournal.kopertais4.or.id/sasambo/index.php/mutaaliyah/article/view/3730

Andrianti, Irawati, \& Sudin. (2016). Pengaruh Pendekatan SAVI (Somatic, Auditory, Visual, Intellectual) Dalam Meningkatkan Kemampuan Komunikasi Matematis Dan Motivasi Belajar Siswa Sekolah Dasar Pada Materi Pengolahan Data. Jurnal Pena Ilmiah, 1(1), 472-480. http://repository.upi.edu/id/eprint/20718

Anika, \& Fajar. (2020). Efektivitas Model Pembelajaran Kooperatif Tipe Make-A Match Dalam Meningkatkan Kompetensi Sikap Siswa dan Kompetensi Pengetahuan Siswa Pada Pelajaran IPS. Jurnal Ilmiah Sekolah Dasar, 4(1), 80-85. http://dx.doi.org/10.23887/jisd.v4i1.24047

Cahyati, A. C., Andriani, L., \& Revita, R. (2020). Pengaruh Penerapan Pendekatan Open Ended terhadap Kemampuan Pemahaman Konsep Matematis Berdasarkan Self. 3(2), 125-132. http://ejournal.uin-suska.ac.id/index.php/juring/article/view/9333.

Daryanto. (2011). Media pembelajaran. Jakarta: PT Raja GrafindoPersada. 
Donas Ahmad Najib \&Elhefni. (2016). Pengaruh Penerapan Pembelajaran Bermakna (Meaningfull Learning) Pada Pembelajaran Tematik IPS Terpadu Terhadap Hasil Belajar Siswa Kelas III di MI Ahliyah IV Palembang. JIP: Jurnal Ilmiah PGMI, 2(1), 19-28. http://jurnal.radenfatah.ac.id/index.php/jip/article/view/1063

Huda, F. A., \& Yulianti, I. (2020). Upaya Meningkatkan Motivasi Dan Hasil Belajar Siswa Menggunakan Model Cooperative Learning Tipe Rotating Trio Exchange ( Rte) Motivasi Belajar , Hasil Belajar Cooperative Learning ( Rte ). 1, 21-26. https://doi.org/10.31932/jutech.v1i1.691

Huda, M. (2014). Cooperative Learning:Metode, Teknik, Struktur, dan Model Penerapan. Yogjakarta: Pustaka Pelajar.

Irfan, \& Nasriadi. (2019). Efektivitas Penerapan Model Pembelajaran SAVI Pada Pembelajaran Pecahan. Jurnal Tunas Bangsa Universitas Majalengka, 6(1). https://ejournal.bbg.ac.id/tunasbangsa/article/view/919

Jailani. (2017). Penggunaan Peta Konsep Untuk Belajar Bermakna Dan Peningkatan Pemahaman Siswa dalam Pembelajaran Biologi. Jurnal Biology Education, 6(1), 30-40. https://doi.org/10.1017/CB09781107415324.004

Khoirudin, M. (2017). Pengaruh Penggunaan Model Pembelajaran Somatis Auditori Visual Intelektual (SAVI) Terhadap Hasil Belajar Matematika Kelas IV SDN 3 Metro Pusat 2017. http://digilib.unila.ac.id/id/eprint/29410

Moma. (2017). Pengembangan Kemampuan Berpikir Kreatif dan Pemecahan Masalah Matematis Mahasiswa Melalui Metode Diskusi. Cakrawala Pendidikan, 36(1), 130-139. Retrieved from https://journal.uny.ac.id/index.php/cp/article/view/10402/pdf

Muniroh, Maftukhin, \& Sriyono. (2015). Efektivitas Model Pembelajaran Somatic Auditory Visual Intelectual (SAVI) untuk Meningkatkan Keaktifan dan Hasil Belajar Fisika Siswa Kelas X SMA Negeri 1 Mirit Tahun Pelajaran 2014/2015. Universitas Muhammadiyah Urworejo, 7(1). http://ejournal.umpwr.ac.id/index.php/radiasi/index

Murti, Nasir, \& Negara. (2019). Analisis Kemampuan Pemecahan Masalah Matematis: Dampak Model Pembelajaran SAVI ditinjau dari Kemandirian Belajar Matematis. Bandar Lampung. Desimal: Jurnal Matematika, 1(1), 2613-9073. Retrieved from http://ejournal.radenintan.ac.id/index.php/desimal/article/view/4072.

Ngalimun. (2017). Strategi Pembelajaran dilengkapi dengan 65 Model Pembelajaran. Yogjakarta: Parama Ilmu.

Puspita, N. M., Asri, I. A. S., \& Ardana, I. K. (2019). Pengaruh Model Pembelajaran Kooperatif Tipe Scramble Berbantuan Media Video Animasi Terhadap Kompetensi Pengetahuan PPKn. Media Komunikasi FPIPS, 17(2), 1-10. https://doi.org/10.23887/mkfis.v17i2.22221

Rahmah, Nur, \& Asnida. (2015). Hubungan Penguasaan Perkalian Dan Pembagian Dasar Terhadap Prestasi Belajar Matematika Siswa Kelas VIII SMP PMDS Putra Palopo. Jurnal Elemen, 1(1), 2442-4228. http://e-journal.hamzanwadi.ac.id/index.php/jel/article/view/81

Ruseffendi. (2006). Pengantar Kepada Guru Mengembangkan kompetensinya dalam Pengajaran Matematika. Bandung: Tarsito.

Sugiyono. (2016). Metodologi Pendidikan. Bandung: Alfabeta.

Sutarna, N. (2018). Pengaruh Model Pembelajaran SAVI (Somatic Auditory Visual Intellectualy) Terhadap Hasil Belajar Siswa Kelas IV Sekolah Dasar Dasar. Profesi Pendidikan, 5(2), 119-126. https://doi.org/10.23917/ppd.v1i2.6068

Umbara, \& Dkk. (2020). Model Pembelajaran Problem Based Learning Berbantuan Media Gambar Seri BerpengaruhTerhadap Kompetensi Pengetahuan IPS Siswa. Jurnal Mimbar Ilmu, 25(2), $174-186$. Retrieved

from https://ejournal.undiksha.ac.id/index.php/MI/article/view/25154/15610

Wati, Darsana, \& Suardika. (2014). Pengaruh Model Pembelajaran Somatic, Auditory, Visual, Intelectual (SAVI) Berbantuan Bahan Ajar Terhadap Hasil Belajar IPS Siswa Kelas V SD Gugus Raden Ajeng Kartini. Mimbar PGSD Undiksha, 2(1). Retrieved from https://ejournal.undiksha.ac.id/index.php/JJPGSD/article/view/3002/2486 
Wiryawan, Murda, \& Bayu. (2019). Hubungan Kebiasaan Belajar Dan Motivasi Berprestasi Dengan Prestasi Belajar PKn. Media Komunikasi FPIPS, 18(1), 189-200. http://dx.doi.org/10.23887/jipp.v3i2.18076 